Vol. 10(14), pp. 2021-2030, 23 July, 2015

DOI: $10.5897 /$ ERR2015.2180

Article Number: 01A1D7E54292

ISSN 1990-3839

Educational Research and Reviews

Copyright (C) 2015

Author(s) retain the copyright of this article

http://www.academicjournals.org/ERR

\title{
Review of the relationship between the college students' attitudes towards love and depression levels
}

\author{
Ahmet SIRIN, Elshad DASHDAMIROV, Durmus UMMET* \\ Marmara University, Ataturk Education Faculty, Department of Psychological Consultation and Guidance, Istanbul, \\ Turkey.
}

Received 13 March, 2015; Accepted 13 July, 2015

\begin{abstract}
This study aims to review the relation between college students' love attitudes and depression levels. Subjects selected were 125 male and 275 female bachelor's and master's degree students; a total of 400 students from various universities in Istanbul in academic year 2013-2014. Data for this study were collected employing both the Love Attitudes Scale (short form) developed by Hendrick et al. based on the love styles classification by Lee, and the Beck Depression Inventory developed by Beck et al. Review of the findings obtained from this study reveals as follows; there are meaningful statistically inverse correlations between the students' depression scores and passionate love attitudes, and meaningful statistically linear correlations between their playful love attitudes and possessive love. No meaningful correlations were found between their other love attitudes and depression level. The findings obtained were discussed with reference to relevant literature and the other studies conducted on this subject, and various suggestions were made under the frame of the findings.
\end{abstract}

Key words: Love, love attitudes, depression, young adult.

\section{INTRODUCTION}

Along with being an essential topic of philosophy and literature, in particular love also became a focus of interest in psychology field. This interest is substantially arises from the desire of understanding the social and psychological traces on human created by being in love. Love is a phenomenon that combines all emotions, behaviors, and attitudes. Not only being able to originate from positive emotions, love may be originated from negative emotions as well. Love related topics were not considered scientific to be analyzed in 1950's and it caused this topic to be ignored. However, psychologists started to reanalyze the topic in last thirty years (Büyükşahin, 2004; Myers and Shurts, 2002; Neto, 2005).
Various researchers explained love in different ways and tried to make a classification of various love forms. Lee stated that approaches towards love are different seeing a black and white picture; therefore, he used colorfulness as a resemblance in order to explain love suggesting the need to compose a colorful picture of love. Being named after Greek words and signified as primary for the first 3 and secondary for the other 3 , there are 6 types of love; passionate love (Eros), friendship love (Storge), game-playing love (Ludus), possessive love (Mania), practical love (Pragma), and altruistic love (Agape). When the description of love concept is examined, determination of the difference between love

\footnotetext{
*Corresponding author. E-mail: dummet@marmara.edu.tr.
}

Authors agree that this article remain permanently open access under the terms of the Creative Commons Attribution License 4.0 International License 
and friendship and the efforts to measure love, Rubin's (1970) emphasis on the differences of emotions felt in love and friendship relations are found to be amongst the first studies on love.

According to Rubin (1970), love is an attitude that combines three compounds such as intimacy, protection and commitment. In the following years, Berscheid and Walster's (1974) passionate love, Walster and Walster's (1978) classification of passionate love and friendship love are among the most comprehensive and the most significant social psychological studies carried out on love. Passionate love is associated with profound desire for being together with the other person, intensive physical arouse (temperature, sweating, dizziness etc.), feeling emptiness in case of a separation with that person and having anxiety. Friendship love is defined as an emotional state which includes endeavoring for the happiness of the other person, taking care of that person, sharing self-disclosure behaviors and experiences correlatively, understanding, compassion, protection, sympathy and deep affection (Hatfield, 1988).

Another frequently mentioned model in the literature is Sternberg's (1986) triangular theory of love. According to this model, love has three important elements. These are passion, intimacy and commitment. Sternberg implied that these components of love can be regarded as a three sided triangle. For this reason, his theory was named as triangular theory of love. According to Sternberg, passion, intimacy and commitment remain in all love relationships at different levels (Cited in Büyükşahin, 2006).

In the literature, it is seen that most of love-related studies are focused on positive emotions of being in love. The findings of the studies on this subject revealed that there are relations at significant levels between positive emotions such as love and happiness, appreciation and satisfaction(cited in Özer and Tezer, 2008) and that love is one of the most important factors which predicts one's state of being well (Masuda, 2003). In addition, it is also seen that there is a relationship between love and negative emotions/psychological state. In the theory of Berscheid and Walster, it was implied that even unpleasant emotional experiences will become a stimulus in love and if they are referred as convenient parts of being in love, they will strengthen the passionate love experience. Therefore, fear, being rejected, being precluded and being opposed might contribute to the emotion of love invariably (Cited in Atkinson, 1999). In the study conducted by Büyükşahin and Hovardaoğlu (2004), love attitudes of couples were analyzed. Researchers obtained the findings that men are more altruistic than women, yet there was not a significant difference between women and men concerning other styles of love. They found a positive relationship between the happiness of couples and altruistic and passionate love styles, and a negative relationship between gameplaying love styles. Especially stupid love (passion and commitment elements), which is a type of love, is a Hollywood style love; in which two people meet each other the way we see it in the movies and soon after they get married. Evolved in time, intimacy is disregarded; a commitment based only on passion is established. They put passion onto the basis of their relationships; yet when the passion decays, they get disappointed. Possessive love (Mania) is a jealous, insecure, obsessive, and slightly pathologic type of love as well. Possessive lovers are in tendency of being insecure about their relationships and they live with the constant fear of losing the partner. Even if the relationship is problematic, people with passionate love usually fail to end it; it is generally the partner who ends the relationship (Büyükşahin, 2004).

Another phenomenon that predicts strong emotions on the individual is depression. Depression is one of the most common disorders among mental illnesses. Due to the different research methods, the conducted data related to frequency and prevalence of depression differentiates. The frequency of depression generally may vary between 9 and $20 \%$ and risk of lifelong depression may vary between 8 and $12 \%$ among men, 20 and 26\% among women (Öztürk, 2004). The word 'depression' in Western languages can be used to define an emotion, a cluster of indication or a manifestation that has diagnosis criteria (Favazza, 1985). Cognitive approach does not accept that causes of depression come from outside. Beck (1967) who stated that depression is a thought disorder more than an feeling, emphasized that evaluating self as worthless, world as meaningless and future as hopeless are the primary elements of depression. According to Beck, negative and decayed mentality, ideas and symbols form the roots of depression (cited in, Boyacıoğlu, 1994). According to this theory, the depressed person feels worthless, insufficient, holds oneself responsible for negative situations and thinks he/she is not liked by others. He/she perceives the relationships with others and experiences in a negative way, thinks that world is full of difficulties that are impossible to overcome. He/she also perceives future as a dark, in failure expectancy and a hopeless state (Savaşır and Yıldız, 1996).

A study examining the relationship between love, which has been examined with its various aspects in the field of psychology in recent years, and depression that is frequently seen in the society is not conducted in our country so far. The inception of this study is to support the forthcoming and similar studies, and to regard the subject as being current.

The general purpose of this study is to determine the relationship between love attitudes of university students and their depression levels. In accordance with this 
purpose, these are the sub-purposes to be answered:

a) Is there any relationship between university students' styles of attitude towards love (including subscales) and their depression levels?

b) Do university students' styles of attitude towards love and depression levels differentiate according to their gender, age, type of universities and previous love experience?

\section{METHOD}

\section{Model of study}

In this study, relational survey model was used to describe evaluating university students' attitudes towards love and their depression levels (Karasar, 1999). Relational survey model was used to examine the university students' attitudes towards love and depression levels in the study.

\section{Study group}

The study group consists of 125 male, 275 female students, in total 400 bachelor and master students in Marmara University and Maltepe University in 2010-2011 academic year.

\section{Data collection instruments}

In order to collect data; personal information form, Love Attitudes Scale (short form), and Beck Depression Inventory were used in the study.

\section{Personal information form}

The form was structured by the researcher aiming to ascertain the demographic features of the university students that participated in the study group.

\section{Love Attitudes Scale (Short Form)}

Based on Lee's (1973) love styles, Love Attitudes Scale: Short Form (LAS) was developed by Hendrick et al. (1998) to determine love styles of people's relationships (Büyükşahin and Hovardaoğlu, 2004). LAS Short Form measured six different love styles as passionate love, friendship love, game-playing love, possessive love, practical love and altruistic love. LAS consists of 24 items, four of them measure each type of love style. The subscales of LAS (short form) consisted of three-item or four-item were obtained by factor analysis in three different studies. Cronbach Alpha reliability coefficient of the subscales range from 0.62 to 0.88 regarding each of the sub-dimension and all of them are significant (Büyükşahin and Hovardaoğlu, 2004). In conclusion, the studies related to the reliability, validity and Turkish adaptation of LAS Short Form indicated that the scale has the required qualifications to be used in studies. Along with psychometric properties, it is also practical for application; therefore, "Love Attitudes Scale: Short Form" was preferred to be used in this study.

\section{Beck Depression Inventory}

Developed by Beck (et al., 1961), Beck Depression Inventory is the
Table 1. The Demographic structure of the study group.

\begin{tabular}{lll}
\hline Gender & F & $\%$ \\
\hline Male & 125 & 31,2 \\
Female & 275 & 68,8 \\
Age & $\mathrm{F}$ & $\%$ \\
$17-19$ ages & 38 & 9,5 \\
$20-22$ ages & 205 & 51,2 \\
$23-25$ ages & 136 & 34,0 \\
26 age and over & 21 & 5,2 \\
Types of University & $\mathrm{f}$ & $\%$ \\
Public University & 230 & 57,5 \\
Private University & 170 & 42,5 \\
Previous Love Experiences & $\mathrm{f}$ & $\%$ \\
Yes & 361 & 90,2 \\
No & 39 & 9,8 \\
Total & 400 & 100,0 \\
\hline
\end{tabular}

most frequently used self-report scale in depression studies. There are two types of BDI: the first is the original 21-question form was developed in 1961 and evaluated the patients' present mood together with patient and clinician. The second 21-question form was developed in 1978 and it is a self-evaluation form and can be applied into groups (cited in Doğan, 2006). Nesrin Hisli Şahin adapted Beck Depression Inventory into Turkish and developed the Turkish Form. Hisli (1988) conducted a validity survey of Beck Depression Inventory with Turkish university students. The studies conducted in both Turkey and abroad indicated that Beck Depression Inventory is a reliable and valid instrument.

\section{Data analysis}

After collecting data, "Beck Depression Inventory" and "Love Attitudes Scale" was scored. Incomplete and incorrect forms were not put to scoring process. SPSS for Windows 16.00 package program was used to analyze and interpret the data collected form "Personal Information Form", "Beck Depression Inventory" and "Love Attitudes Scale".

\section{FINDINGS}

The range of demographic variables of the students that participated in the study is shown in Table 1.

As seen from Table 2, it was found out that there was a linear but statistically insignificant relationships (total attitude, $\quad r=, 060$; practical attitude $r=, 060$; altruistic attitude, $r=, 064$;) between the students' total depression scores and love attitudes styles ( $p>, 050)$. In other words, the more students' depression scores increase, the more their total love, practical love and altruistic love attitudes scores increase though being statistically insignificant. It was also found out in the same table that there was a statically insignificant inverse relationship ( $p>050)$ between the students' depression scores and friendship 
Table 2. The results of Pearson product-moment correlation coefficient for determining between students' depression levels and styles of love attitudes (total, passionate, game-playing, friendship, practical, possessive and altruistic love sub-scales).

\begin{tabular}{|c|c|c|c|c|c|c|c|}
\hline & 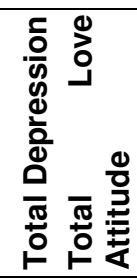 & $\begin{array}{l}0 \\
0 \\
0 \\
0 \\
0 \\
0 \\
0 \\
0 \\
0 \\
0 \\
0\end{array}$ & 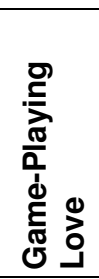 & 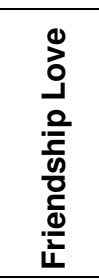 & 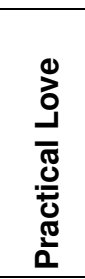 & 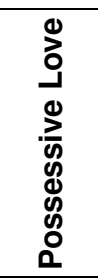 & $\begin{array}{l}0 \\
0 \\
0 \\
0 \\
0 \\
\frac{0}{3} \\
\frac{2}{ \pm} \\
\frac{1}{2}\end{array}$ \\
\hline Total Depression & $r=1,060$ &,$- 165^{* *}$ &, $118^{*}$ &,- 050 & ,060 & ,203* & 064 \\
\hline Total Love Attitude & $r=1$ & $629^{* *}$ & ,259** &, $584^{* *}$ &, $493^{* *}$ & $612^{* *}$ & $694^{* *}$ \\
\hline Passionate Love & & $r=1$ &,- 059 & ,348** &, $144^{* *}$ &, $163^{* *}$ & ,428* \\
\hline Game-Playing Love & & & $r=1$ &,- 005 & ,063 &, $162^{* *}$ &,- 074 \\
\hline Friendship Love & & & & $r=1$ & 075 &, $120^{*}$ & ,233** \\
\hline Practical Love & & & & & $r=1$ & ,219** & , 171" \\
\hline Possessive Love & & & & & & $r=1$ &, $405^{* *}$ \\
\hline Altruistic Love & & & & & & & $r=1$ \\
\hline
\end{tabular}

Table 3. The results of independent group t-test to determine whether the students' depression levels differentiated by their genders.

\begin{tabular}{|c|c|c|c|c|c|c|c|}
\hline \multirow{2}{*}{ Score } & \multirow{2}{*}{ Gender } & \multirow{2}{*}{$\mathbf{N}$} & \multirow{2}{*}{$\overline{\mathrm{X}}$} & \multirow{2}{*}{ SS } & \multirow{2}{*}{$\mathrm{Sh}_{\overline{\mathrm{x}}}$} & \multicolumn{2}{|c|}{$t$ Test } \\
\hline & & & & & & Sd & $\mathbf{T}$ \\
\hline \multirow{2}{*}{ Gender } & Male & 125 & 31,99 & 9,13 & 0,81 & \multirow{2}{*}{398} & \multirow{2}{*}{$\begin{array}{l}-, 223 ; \\
\text { p> ,398 }\end{array}$} \\
\hline & Female & 275 & 32,22 & 9,94 & 0,59 & & \\
\hline
\end{tabular}

love attitudes $(r=, 0,50)$. In other words, the more students' depression scores increase, the more their friendship love attitudes decrease though being statistically insignificant. Another finding showed that there was a statistically significant inverse relationship $(p<, 050)$ between the students' depression scores and passionate love attitudes styles $(r=-, 165)$ whereas there was a statistically significant linear relationship between game-playing love attitudes and possessive love attitudes $(r=, 203)$. In other words, when students' depression scores increase, their passionate love attitudes scores decrease; however, their game-playing love attitudes and possessive love attitudes scores statistically increase.

When Table 3 was examined, it was ascertained that there was no statistically significant differentiation between the groups according to the results of independent group t-test conducted to determine whether the students' depression levels differentiate by their genders $(p>, 050)$. That is to say, depression levels of the students do not differentiate by their gender.
When Table 4 was examined, it was ascertained that there was no statistically significant differentiation between the groups according to the results of independent group t-test conducted to determine whether the students' love attitudes styles (total, passionate, gameplaying, friendship, practical, possessive and altruistic love sub-scales) differentiate by their genders ( $p>, 050)$. In other words, the scores of students' love attitudes styles (total, passionate, game-playing, friendship, practical, possessive and altruistic love sub-scales) do not differentiate statistically significant according to their genders.

According to the results of Kruksal Wallis-H Test conducted on the purpose of determine whether the students' depression levels are differentiated by their age or not, the difference among average scores of the groups was found as statistically insignificant $(p>, 05)$. In other words, the depression levels of students do not differentiate by their ages.

According to the results of Kruksal Wallis-H Test conducted to determine whether the students' love attitudes styles (total, passionate, game-playing, friendship, practical, possessive and altruistic love sub-scales) differentiate by their age or not, the difference among average scores of the groups was found as statistically insignificant $(p>, 05)$. In other words, students' love attitudes styles (total, passionate, game-playing, friend-ship, practical, possessive and altruistic love sub-scales) do not significantly differentiate from their ages (Table 6).

When Table 7 was examined, it was found out that there was no statistically significant differentiation between 
Table 4. The results of independent group t-test to determine whether the students' love attitudes styles (total, passionate, game-playing, friendship, practical, possessive and altruistic love sub-scales) differentiate by their genders.

\begin{tabular}{llllllll}
\hline \multirow{2}{*}{ Score } & \multirow{2}{*}{ Gender } & $\mathbf{n}$ & $\overline{\mathrm{x}}$ & SS & $\mathrm{Sh}_{\overline{\mathrm{x}}}$ & \multicolumn{2}{c}{$t$ Test } \\
\cline { 7 - 8 } Passionate & Male & 125 & 14,08 & 3,12 & 0,27 & & $\mathbf{T}$ \\
& Female & 275 & 14,17 & 3,07 & 0,18 & & $\mathrm{p}>, 555$ \\
\multirow{2}{*}{ Game-Playing } & Male & 125 & 11,16 & 2,63 & 0,23 & & 2,$842 ;$ \\
& Female & 275 & 10,38 & 2,51 & 0,15 & & $\mathrm{p}>, 329$ \\
Friendship & Male & 125 & 11,67 & 3,57 & 0,32 & &,$- 011 ;$ \\
& Female & 275 & 11,67 & 3,86 & 0,23 & & $\mathrm{p}>, 362$ \\
Practical & Male & 125 & 11,32 & 3,19 & 0,28 & \multirow{2}{*}{398} & $-3,954 ;$ \\
& Female & 275 & 12,63 & 3,02 & 0,18 & & $\mathrm{p}>, 479$ \\
Possessive & Male & 125 & 11,83 & 3,13 & 0,28 & & $-2,548 ;$ \\
& Female & 275 & 12,66 & 2,96 & 0,17 & & $\mathrm{p}>, 859$ \\
Altruistic & Male & 125 & 12,66 & 3,77 & 0,33 & & 3,$579 ;$ \\
\multirow{2}{*}{ Total } & Female & 275 & 11,25 & 3,60 & 0,21 & & $\mathrm{p}>, 486$ \\
& Male & 125 & 72,73 & 12,03 & 1,00 & &,$- 039 ;$ \\
& Female & 275 & 72,78 & 10,18 & 0,61 & & $\mathrm{p}>, 289$ \\
\hline
\end{tabular}

Table 5. The results of Kruksal Wallis $-\mathrm{H}$ test to determine whether the students depression levels differentiated by their ages.

\begin{tabular}{lllllll}
\hline Score & Age & $N$ & $\bar{x}_{\text {sira }}$ & $x^{2}$ & $s d$ & $p$ \\
\hline \multirow{5}{*}{ Depression Levels } & $17-19$ ages & 38 & 184,96 & & & \\
& $20-22$ ages & 205 & 202,25 & & & \\
& $23-25$ ages & 136 & 197,75 & 2,121 & 3 &, 548 \\
& 26 age and over & 21 & 229,33 & & & \\
& Total & 400 & & & & \\
\hline
\end{tabular}

the groups according to the results of independent group t-test conducted to determine whether or not the students' depression levels differentiate by the types of universities $(p>, 050)$. In conclusion, depression levels of the students who participated in this research do not differentiate by the types of universities that they are studying at.

When Table 8 was examined, it was indicated that there was no statistically significant differentiation between the groups according to the results of independent group t-test conducted to determine whether the students' love attitudes styles (total, passionate, game-playing, friendship, practical, possessive and altruistic love sub-scales) differentiate by the types of universities $(p>, 050)$. In other words, the scores of students' love attitudes styles (total, passionate, gameplaying, friendship, practical, possessive and altruistic love sub-scales) do not differentiate statistically significant according to the types of university. However, it was found out that the scores of students' practical love attitudes statistically differentiate by the types of universities that they are going $(p<, 010)$. This differentiation resulted in favor of the students who have been educating in private universities. In other words, private university students have more significant practical love attitudes than the public university students.

When Table 9 was examined, it was ascertained that there was statistically significant differentiation between the groups according to the results of independent group t-test conducted to determine whether the students' depression levels differentiate by their previous love experiences $(p<, 050)$. This differentiation derived from the students that do not have any previous love experiences. In conclusion, students that do not have any previous love experiences have more significant depression levels than the ones who have previous love experiences.

According to Table 10, it was found out that there was 
Table 6. The results of Kruksal Wallis - $\mathrm{H}$ test to determine whether the students' love attitudes styles (total, passionate, game-playing, friendship, practical, possessive and altruistic love sub-scales) differentiated by their ages.

\begin{tabular}{|c|c|c|c|c|c|c|}
\hline Score & Age & $N$ & $\bar{x}_{\text {sira }}$ & $x^{2}$ & $s d$ & $p$ \\
\hline \multirow{4}{*}{ Passionate } & $17-19$ ages & 38 & 223,43 & & \multirow{4}{*}{3} & \multirow{4}{*}{, 156 } \\
\hline & $20-22$ ages & 205 & 195,13 & 5,219 & & \\
\hline & $23-25$ ages & 136 & 208,45 & & & \\
\hline & 26 age and over & 21 & 159,95 & & & \\
\hline \multirow{4}{*}{ Game-Playing } & $17-19$ ages & 38 & 169,63 & \multirow{4}{*}{3,125} & \multirow{4}{*}{3} & \multirow{4}{*}{,373 } \\
\hline & $20-22$ ages & 205 & 202,35 & & & \\
\hline & $23-25$ ages & 136 & 205,15 & & & \\
\hline & 26 age and over & 21 & 208,19 & & & \\
\hline \multirow{4}{*}{ Friendship } & $17-19$ ages & 38 & 208,42 & \multirow{4}{*}{,813 } & \multirow{3}{*}{3} & \multirow{3}{*}{,846 } \\
\hline & 20-22 ages & 205 & 198,40 & & & \\
\hline & $23-25$ ages & 136 & 204,03 & & & \\
\hline & 26 age and over & 21 & 183,86 & & & \\
\hline \multirow{3}{*}{ Practical } & $17-19$ ages & 38 & 197,43 & \multirow{3}{*}{3,790} & \multirow{3}{*}{3} & \multirow{3}{*}{,285 } \\
\hline & $20-22$ ages & 205 & 200,84 & & & \\
\hline & 23-25 ages & 136 & 207,79 & & & \\
\hline \multirow{5}{*}{ Possessive } & 26 age and over & 21 & 155,48 & \multirow{5}{*}{2,516} & \multirow{5}{*}{3} & \multirow{5}{*}{,472 } \\
\hline & $17-19$ ages & 38 & 221,93 & & & \\
\hline & $20-22$ ages & 205 & 194,62 & & & \\
\hline & 23-25 ages & 136 & 205,75 & & & \\
\hline & 26 age and over & 21 & 185,14 & & & \\
\hline \multirow{3}{*}{ Altruistic } & $17-19$ ages & 38 & 222,12 & \multirow{3}{*}{4,566} & \multirow{3}{*}{3} & \multirow{3}{*}{,206 } \\
\hline & 20-22 ages & 205 & 194,69 & & & \\
\hline & 23-25 ages & 136 & 208,72 & & & \\
\hline \multirow{6}{*}{ Total } & 26 age and over & 21 & 164,81 & \multirow{6}{*}{5,032} & \multirow{6}{*}{3} & \multirow{6}{*}{, 169} \\
\hline & $17-19$ ages & 38 & 218,36 & & & \\
\hline & 20-22 ages & 205 & 194,16 & & & \\
\hline & $23-25$ ages & 136 & 211,06 & & & \\
\hline & 26 age and over & 21 & 161,67 & & & \\
\hline & Total & 400 & & & & \\
\hline
\end{tabular}

Table 7. The results of independent group t-test to determine whether the students' depression levels differentiated by the types of universities.

\begin{tabular}{llllllll}
\hline Score & University & $\mathbf{n}$ & $\overline{\mathrm{x}}$ & $\mathbf{S S}$ & $\mathrm{Sh}_{\overline{\mathrm{x}}}$ & \multicolumn{2}{c}{$t$ Test } \\
\hline \multirow{2}{*}{$\begin{array}{l}\text { Types } \\
\text { of university }\end{array}$} & $\begin{array}{l}\text { Public } \\
\text { University }\end{array}$ & 230 & 32,09 & 9,23 & 0,60 & & $\mathbf{T}$ \\
& $\begin{array}{l}\text { Private } \\
\text { University }\end{array}$ & 170 & 32,22 & 10,30 & 0,79 & & $\begin{array}{l}-, 136 ; \\
\mathrm{p}>, 414\end{array}$ \\
\hline
\end{tabular}

no statistically significant differentiation between the groups according to the results of independent group ttest conducted to determine whether the students' love attitudes styles (total, passionate, game-playing, friendship, practical, possessive and altruistic love subscales) differentiate by their previous love experiences variables ( $p>, 050)$. In other words, the scores of students' love attitudes styles (total, passionate, game-playing, 
Table 8. The results of independent group t-test to determine whether the students' love attitudes styles (total, passionate, game-playing, friendship, practical, possessive and altruistic love sub-scales) differentiated by the types of universities.

\begin{tabular}{|c|c|c|c|c|c|c|c|}
\hline \multirow{2}{*}{ Score } & \multirow{2}{*}{ University } & \multirow{2}{*}{$\mathbf{N}$} & \multirow{2}{*}{$\overline{\mathrm{X}}$} & \multirow{2}{*}{ SS } & \multirow{2}{*}{$\mathrm{Sh}_{\overline{\mathrm{x}}}$} & \multicolumn{2}{|c|}{$t$ Test } \\
\hline & & & & & & Sd & $\mathbf{T}$ \\
\hline \multirow{2}{*}{ Passionate } & Public & 230 & 14,25 & 3,06 & 0,20 & \multirow{14}{*}{398} & ,807; \\
\hline & Private & 170 & 14,00 & 3,12 & 0,23 & & $p>, 515$ \\
\hline \multirow{2}{*}{ Game-Playing } & Public & 230 & 10,45 & 2,48 & 0,16 & & $-1,610$ \\
\hline & Private & 170 & 10,87 & 2,67 & 0,20 & & $p>, 638$ \\
\hline \multirow{2}{*}{ Friendship } & Public & 230 & 11,63 & 3,59 & 0,23 & &,- 248 \\
\hline & Private & 170 & 11,72 & 4,00 & 0,30 & & $p>, 105$ \\
\hline \multirow{2}{*}{ Practical } & Public & 230 & 11,95 & 2,88 & 0,19 & & $-2,015$ \\
\hline & Private & 170 & 12,58 & 3,41 & 0,26 & & $\mathrm{p}>, 010^{\star *}$ \\
\hline \multirow{2}{*}{ Possessive } & Public & 230 & 12,45 & 3,03 & 0,20 & & ,413; \\
\hline & Private & 170 & 12,32 & 3,05 & 0,23 & & $p>, 763$ \\
\hline \multirow{2}{*}{ Altruistic } & Public & 230 & 11,64 & 3,71 & 0,24 & &,- 307 \\
\hline & Private & 170 & 11,75 & 3,71 & 0,28 & & $p>, 624$ \\
\hline \multirow{2}{*}{ Total } & Public & 230 & 72,39 & 9,90 & 0,65 & &,- 810 \\
\hline & Private & 170 & 73,27 & 11,90 & 0,91 & & $p>, 078$ \\
\hline
\end{tabular}

${ }^{*} p<.05 ;{ }^{* *} p<.01 ;{ }^{* * *} p<.001$.

Table 9. The results of independent group t-test to determine whether the students' depression levels differentiated by their previous love experiences variables.

\begin{tabular}{|c|c|c|c|c|c|c|c|}
\hline \multirow{2}{*}{ Score } & \multirow{2}{*}{$\begin{array}{l}\text { Love } \\
\text { Experiences }\end{array}$} & \multirow{2}{*}{$\mathbf{N}$} & \multirow{2}{*}{$\overline{\mathrm{X}}$} & \multirow{2}{*}{ ss } & \multirow{2}{*}{$\mathrm{Sh}_{\bar{x}}$} & \multicolumn{2}{|c|}{$t$ Test } \\
\hline & & & & & & Sd & $T$ \\
\hline $\begin{array}{l}\text { Love } \\
\text { Experiences }\end{array}$ & $\begin{array}{l}\text { Yes } \\
\text { No }\end{array}$ & $\begin{array}{l}361 \\
39\end{array}$ & $\begin{array}{l}31,88 \\
34.66\end{array}$ & $\begin{array}{l}9,27 \\
12,81\end{array}$ & $\begin{array}{l}0,48 \\
2,05\end{array}$ & 398 & $\begin{array}{l}-1,709 \\
\mathrm{D}<048^{*}\end{array}$ \\
\hline
\end{tabular}

${ }^{*} \mathrm{p}<.05 ;{ }^{* *} \mathrm{p}<.01 ;{ }^{* * *} \mathrm{p}<.001$.

friendship, practical, possessive and altruistic love subscales) do not differentiate statistically significant according to their previous love experiences.

\section{DISCUSSION AND CONCLUSION}

Discussions concerning the findings obtained as a result of the conducted study and suggestions brought forward within this framework are covered below:

Linear yet statistically insignificant relationship was obtained between total depression and love attitude styles scores of students who participated in this survey. It was indicated that there was an inverse yet statistically insignificant relationship between students' depression scores and friendship love attitudes scores. It was stated that there was a statistically inverse relationship between depression scores and passionate love attitude scores; and a statistically linear relationship between game- playing love attitudes and possessive love attitudes scores.

The results of the analysis conducted to examine the relationship between love styles and depression levels of students, a statistically significant inverse relationship between passionate love and depression level was obtained. When related literature was examined, Arnold and Thompson (1995) analyzed the relationship between love forms and personality disorders. People with passionate love types have lower scores on the depression scales. The findings coincide with the literature. When examining the literature, it was seen that Hatfield and Walster defined passionate love as the intensive desire for becoming a whole with one another. When it is a mutual feeling, it is correlated with sense of integration and pleasure. In cases of rejection, it causes emotions as emptiness, anxiety, jealousy, pain, and hopelessness. Consequently, passionate love is a profound state of psychological stimulus (Cited in Curun, 
Table 10. The results of independent group t-test to determine whether the students' love attitudes styles (total, passionate, game-playing, friendship, practical, possessive and altruistic love sub-scales) differentiated by their previous love experiences variable.

\begin{tabular}{|c|c|c|c|c|c|c|c|}
\hline \multirow{2}{*}{ Score } & \multirow{2}{*}{ Gender } & \multirow{2}{*}{$\mathbf{N}$} & \multirow{2}{*}{$\overline{\mathrm{X}}$} & \multirow{2}{*}{ sS } & \multirow{2}{*}{$\mathrm{Sh}_{\overline{\mathrm{x}}}$} & \multicolumn{2}{|c|}{$t$ Test } \\
\hline & & & & & & Sd & $T$ \\
\hline \multirow{2}{*}{ Passionate } & Yes & 361 & 14,22 & 3,093 & 0,16 & \multirow{14}{*}{398} & 1,621 \\
\hline & No & 39 & 13,38 & 2,97 & 0,47 & & $p>, 495$ \\
\hline \multirow{2}{*}{ Game-Playing } & Yes & 361 & 10,67 & 2,60 & 0,13 & & 1,019 \\
\hline & No & 39 & 10,23 & 2,31 & 0,37 & & $p>, 126$ \\
\hline \multirow{2}{*}{ Friendship } & Yes & 361 & 11,65 & 3,81 & 0,20 & &,- 253 \\
\hline & No & 39 & 11,82 & 3,33 & 0,53 & & $p>, 128$ \\
\hline \multirow{2}{*}{ Practical } & Yes & 361 & 12,18 & 3,14 & 0,16 & &,- 824 \\
\hline & No & 39 & 12,61 & 3,00 & 0,48 & & $p>, 555$ \\
\hline \multirow{2}{*}{ Possessive } & Yes & 361 & 12,36 & 3,03 & 0,15 & &,- 793 \\
\hline & No & 39 & 12,76 & 3,07 & 0,49 & & $p>, 630$ \\
\hline \multirow{2}{*}{ Altruistic } & Yes & 361 & 11,70 & 3,72 & 0,19 & &, 136 \\
\hline & No & 39 & 11,61 & 3,63 & 0,58 & & $p>, 494$ \\
\hline \multirow{2}{*}{ Total } & Yes & 361 & 72,80 & 10,77 & 0,56 & & ,202; \\
\hline & No & 39 & 72,43 & 11,06 & 1,77 & & $p>, 197$ \\
\hline
\end{tabular}

2004). Beştav (2007) also stated in her research that mostly passionate love style predicts relationship satisfaction of individuals. Therefore, having passionate love attitude, though it may cause negative psychological states on the individual, is a subsidiary for positive feelings as well.

The findings indicated that there is statistically significant linear relationship between the students' depression levels and game-playing and possessive love attitude. In the study of Arnold and Thompson (1995), it was seen that people with possessive and game-playing love have higher scores in depression scales. When examining the literature which explains attitudes towards love, it can be seen that obtained results are concordant to a large extent. Game-playing love is the love that couples carefully control relationship stages by avoiding making long-term plans and giving promises. These types of people generally have more than one partner and their relationships are short-dated. Therefore, in this love type which is not regular and steady, it is subjected that individuals encounter many problems and life stress in time and these negative situations will cause them to become more prone to depression. However, possessive love attitude is a love type which can be characterized as excessive emotionality, jealousy and obsession. Individuals get jealous of their partners from real or unreal rivals and feel destroyed in case of a rejection. Most of the time, depression and tension cause their relationship to be deteriorated (Lee 1973; 1977). In the first study conducted by Büyükşahin and Hovardaoğlu (2004), they found a negative relationship between game-playing love style and the happiness of the couple. Beştav (2007) stated that there was a linear relationship between game-playing love attitude and irrational beliefs (as it is found in depression cognitive dimension) in the study which analyzes the relationship between love attitudes and negative automatic thoughts. In the study of Düzgün (2009), it was determined that there is a negative relationship between romantic satisfaction in marriage and depression levels of partners.

In this study, it was stated that there was not a statistically significant difference in students' depression scores among the groups by gender variable. Examining the studies, research and literature related to the subject, it was seen that there were findings both concordant and discordant with the obtained findings. Some of the conducted studies (Koç, 2008; Yiğit and Yılmaz, 2011; Çelik and Acar, 2007) presented findings as individuals' depression levels do not differentiate by gender. Öngider and Eyüpoğlu (2013); Bingöl, Demir, and Karabek (2010) stated that depression is more common among women and Otacıoğlu (2008) stated that it is more common among men. All these findings give rise to the thought that depression is not a state only connected with the gender, and it finds meaning when different variables such as negative life-events, individual's cognitive structures, financial characteristics are involved.

It was seen that students' attitudes towards love do not differentiate by gender. Obtained findings are concordant with similar studies to a large extent. Büyükşahin and Hovardaoğlu (2004) examined the couples' love attitudes. Researchers attained the findings that men are more 
altruistic than women, yet there was not a significant difference between men and women regarding the other love types. In her study examining love attitudes, Beştav (2007) stated that love attitudes by gender do not show a significant difference. However, Tüfekçi (2008), Neto (1994), and Ercan (2008) attained the correlated findings in their studies that men have game-playing and altruistic love attitudes more than women, and there was not any difference in the other types of love. It can be suggested that these findings are correlated with the fact that women have more emotional personal characteristics and feel the emotions about love more effectively; men, on the other hand, experience this process without focusing to emotions too much.

It was seen that students' depression level scores do not statistically differentiate by age variable. Studies conducted with several sample groups concerning this subject reveal different findings about the age variable. Eyüpoğlu (2009) stated that adolescents experience depression more deeply, Otacioğlu (2008) and Koç (2008) stated that individuals' depression levels do not differentiate by age, while Yiğit (2008) and Bingöl et al. (2010) stated that the more age increases, the depression level increases as well. With reference to the hypothesis that different dynamics become active in depression, it can be suggested that the variances in these findings were expectable. It was also found out that students' love attitudes towards love do not differentiate by their ages.

It was seen that student's depression scores do not statistically differentiate according to types of university. Depression is a problem which has cognitive, affective and behavioral dimensions (Köroğlu, 1997). Being a woman, an adolescent or elderly, low socio-economic level, being divorced or widow, having depression history in the family, stressful life-events are indicated as significant risk factors for major depression development (Savrun, 1999). As it can be seen in this information listed about depression, predictive variables of depresssion can happen in all settings and to all individuals.

It was seen that students' love attitudes also do not differentiate by university types. Yet, it was seen that university students' practical love attitude scores vary statistically by university types. This differentiation resulted in favor of the students who have been educating in private universities. Practical love is a love type which has historical origins such as arranged marriage or partnership can associated with finding a partner on the internet in the modern times. These type of people consider the other person's education level, religion, age, family, friends, etc. before they involve in the relationship. They are loyal when they make a reasonable selection. Sexual intercourse is relatively insignificant (Lee, 1973, 1977). Examining the literature related to practical love, it is an expectable finding that love attitudes may be at higher levels among private university students. Because, these individuals who are at a higher level in financial terms usually tend to prefer people at the same level as their own in love, as well and experience their emotional relationships in this state-of-mind.

Examining the students' depression scores according to their previous love experiences, it was ascertained that depression levels of students that do not have any previous love experience is statistically higher at a significant level comparing to students that have a previous love experience. As a similar finding, in the study conducted by Eyüpoğlu (2009), it was found that married people experienced lower depression levels.

It was seen that students' love attitudes styles do not vary according to their previous love experiences. As a similar finding relating the subject, in the study conducted by Tüfekçi (2008) it was stated that individuals with an emotional relationship have passionate and altruistic love attitudes more than people with any emotional relationship. As for the other types of love, it does not differentiate according to the fact whether or not the individual has an emotional relationship. A parallel finding was subjected in this study as well.

In the context of obtained finding, the suggestions brought forward are presented below:

Love is a topic which human beings emphasize frequently in literary works and songs, and which occupies an individual's agenda considerably at a certain stage of life with a few exceptions. In our country there is not adequate scientific study about love, which has various effects on mental health of an individual as it, is an excessive emotional state. It is considered that carrying out more scientific studies about love and love-related topics is important especially in the field of psychological counseling and guidance.

Love and love attitudes of individuals are the phenomena that involve what happened in an individual's private life, and although it is tried to be identified, they are known as to be personally identifiable. Therefore, it can be suggested that it is essential to support qualitative research with quantitative research in order to be able to reach excessive information about love.

\section{Conflict of Interests}

The author(s) have not declared any conflict of interests.

\section{REFERENCES}

Arnold ME, Thompson B (1995). Love style perceptions in relation to personality function. J. Social Behavior \& Personality, 11 (3): 1-9

Atkinson RL, Atkinson RC (1999). Psychology, an Introduction. Ankara: Arkadas publising.

Beck AT (1967). Depression: Clinical experimental and theoretical aspects. Harpertand Row, New York. 
Berscheid E, Walster E (1974). A little bit about love. In Huston T. (Ed.), Foundations of interpersonal attraction. New York: Academic Press.

Beştav FG (2007). Examination of among satisfaction of romantic relationship and gender, attachment styles, irrational thinkings and love attitudes. Post graduate, Hacettepe University, Ankara, Turkey.

Bingöl G, Demir A, Karabek R, Kepenek B, Yıldııım N, Kaytaz EG (2010). Investigation of some variables of depression level in people who over 65 years, Göztepe Medicine J. 25(4):169-176.

Boyacıoğlu G (1994). The relation between depressive symptoms and personel schema in collage students. Clinical psycology programme. Ankara: Hacettepe University publising.

Büyükşahin A, Hovardaoğlu S (2004). An examination of couples' A Study of Couples Love Attitudes Within Lee's Multidimensional Love Styles Framework. Turk. Psychol. J. 19 (54): 59-72.

Curun F (2004). Passionate love and friendly love. Turk. Psychol. J. (32):116-120

Çelik HC, Acar T (2007). The Investigation of depression and anxiety level of chronic hemodialysis patients according to different variables. Firat Universty Medicine J. 12(1): 23-27.

Ercan H (2008). Love styles and self types of young adults. Master thesis, Ankara Universtiy.

Favazza AR (1985). Anthropology and psychiatry. Comprehensive Textbook of Psychiatry, HI Kaplan, BJ Sadock (Ed), 4. Baskı, 1. Cilt, Baltimore, Williams \& Wilkins, s. 247-265.

Hatfield E (1988). Passionate and companiate love. In Sternberg RJ, Barnes ML (Eds.), The Psychology of Love. New Haven: Yale University Press

Koç V (2008). Interpersonal style, self-perception, anger and depression, Master thesis, Ankara Üniversitesi.

Köroğlu E (1997). Major depression disorder. Psychiatry basic book. Ankara (edt.: Güleç, C, Doctors common publising: 389-421.

Lee JA (1973). The colors of love: An exploration of the ways of loving. Toronto: New Pres.

Lee JA (1977). A typolgy of styles of loving. Personality and social Psychology Bulletin, 3: 173-182.

Myers JE, Shurts WM (2002). Measuring Positive Emotionality: A Review of Instruments Assessing Love. Measurement and Evaluation in Counseling and Development, 34: 238-254.

Neto F (1993). Love styles and self-representations. Personality and Individual Differences, 14, 795-803.

Otacıoğlu SG (2008). A relation analysis on the levels of music teacher' sociotropic and autonomic personality characteristics with depression, Eskişehir Osmangazi University, Social sciences journal, 9 (1).
Öngider N, Eyüpoğlu SÖ (2009). Investigation of Death Anxiety Among Depressive Patients, Clinical Psychiatry J. 16:34-46.

Özer B, Tezer E (2008). Love attitude styles as the predictors of positive and negative affect. Turkish Psychological and Counselling J. 30 (3):19-25.

Öztürk MO (2004). Mental health and disorders. (10. baskı). Nobel medicine bookstore: Ankara. 291-342.

Rubin Z (1970). Mesurement of romantic love. J. Personality and Social Psychol. 16: 265-273.

Savrun M (1999). Definition and epidemiology of depression. İstanbul University Cerrahpaşa Medicine Faculty, medicine conferances. 1117.

Savaşır İ, Yıldız S (1996). Cognitive-behavior therapy in depression. Turkish psychology assosation publising, no:7.

Sternberg RJ (1986). A trangular theory of love. Psychological Rev. 93: 119-135.

Tüfekçi S (2008). An assessment of love attıtudes and characterıstıcs of young adults in romantic relationships in terms of transactional analys Is ego states. Master thesis, Marmara University.

Walster E, Walster GW (1978). A New at Love. NewYork: McGraw.

Yiğit R, Yımaz H (2011). The research of the relationship between the social skill levels of elementary II level students and their self-esteem. Selcuk University Journal of Ahmet Kelesoglu Education Faculty, 31: 335-347. 